\title{
Hyperprolinemia type 1
}

INSERM

\section{Source}

INSERM. (1999). Orphanet: an online rare disease and orphan drug data base.

Hyperprolinemia type 1. ORPHA:419

Hyperprolinaemia type I is an inborn error of proline metabolism characterised by elevated levels of proline in the plasma and urine. The prevalence is unknown. The disorder is generally considered to be benign but associations with renal abnormalities, epileptic seizures, and other neurological manifestations, as well as certain forms of schizophrenia have been reported. It is transmitted as an autosomal recessive trait and is caused by mutations in the proline dehydrogenase or proline oxidase gene (PRODH or POX, 22q11.2). 